\title{
TOWARDS THE IMPLEMENTATION OF E-MANUFACTURING: DESIGN OF AN AUTOMATIC TEA DRYING CONTROL SYSTEM
}

\author{
N. Mabvuu ${ }^{1}$, L. Nyanga ${ }^{2 *}$, A. F. van der Merwe ${ }^{3}$, S. Matope ${ }^{4} \&$ S. Mhlanga ${ }^{5}$ \\ ${ }^{1,5}$ Department of Industrial and Manufacturing Engineering \\ National University of Science and Technology, Zimbabwe \\ ${ }^{2,3,4}$ Department of Industrial Engineering \\ Stellenbosch University, South Africa \\ 2inyanga@sun.ac.za, 3andrevdm@sun.ac.za, ${ }^{4}$ smatope@sun.ac.za
}

\begin{abstract}
Many of the production costs for producing tea are attributable to the process of drying the tea. E-manufacturing can assist companies to reduce these production costs by making crucial information available to decision-makers so that they can make informed decisions. This paper presents an application of e-manufacturing to the design of an automatic tea drying control system. This control system will ensure that the multiple drying parameters such as temperature, dryer-exit tea moisture content, and fuel consumption are maintained at optimal states during the course of the drying of tea. The additional aim of this system is to balance the cost of production and the quality of the final product. Using the Guggenheim-Anderson-De Boer (GAB) model, the optimum drying temperature was found to be $100-110^{\circ} \mathrm{C}$, while maintaining a dryer-exit tea moisture content of 3 to 3.12 per cent, at a drying rate of 3 per cent per minute. A Barix control application to control the system's activities, using the web user interface (WUI), was also developed.
\end{abstract}

\section{OPSOMMING}

' $n$ Groot gedeelte van die koste in die produksie van tee is as gevolg van die teedroogproses. E-vervaardiging kan die produksiekoste verminder deur kritiese inligting vir die besluitnemers beskikbaar te stel. Hierdie studie beskryf ' $n$ toepassing van e-vervaardiging op die ontwerp van ' $n$ outomatiese tee-droog beheerstelsel. Die beheerstelsel verseker dat al die droogparameters, soos temperatuur, voggehalte en brandstofverbruik, by optimum toestande beheer word deur die loop van die droogproses. Verder word daar deur die beheerstelsel ' $n$ balans tussen die produksiekoste en die gehalte van die finale produk gehandhaaf. Deur van die Guggenheim-Anderson-De Boer (GAB) model gebruik te maak, is die optimale droogtemperatuur gevind om tussen 100 tot $110^{\circ} \mathrm{C}$ te lê, terwyl die droëruitlaatvoggehalte tussen 3 en $3.12 \%$ met 'n droogtempo van $3 \%$ per minuut te lê. 'n Barix beheer program is ontwikkel om die beheerstelsel se werksaamhede te monitor.

\footnotetext{
2 The paper was written in support of L. Nyanga's PhD research on the development of an emanufacturing model for the South African industry.

* Corresponding author
} 


\section{INTRODUCTION}

There is no alternative to drying tea, which is the most energy-intensive and most expensive process in the manufacture of tea, as stated by Saeed[1]. For Zimbabwean tea companies that experience high energy costs, there is a need for innovation in this area that balances the cost of production and the quality of the final product. In order to reach this balance, the factory needs to be constantly monitored by decision-makers in order to obtain the correct and appropriate information on the factory's processes. Developments in information technology and the development of e-manufacturing concepts have enabled inventions of new and better methods to provide information, monitor, and keep processes under control in a factory. This paper presents the design of an online automatic tea drying control system for a tea company based in Zimbabwe. The design aims to eliminate errors associated with the dependency on people who currently regulate the dryer environment in tea production. Currently, the drier operator controls the dryer by monitoring the drier exit tea, feeling and smelling the tea in order to determine the moisture content of this tea. The intention of this paper is therefore to present a design that will continuously monitor and control the temperature, humidity, and pressure inside a drier. In addition, the fuel feed system can be automated.

\section{E-MANUFACTURING}

E-manufacturing refers to the ability of a manufacturing system to integrate various inputs using the internet and the intranet. Depending on the focus of its application, emanufacturing has different meanings for different sets of people. The most popular definition of e-manufacturing, which is made by AMR [2], defines it as a strategy that takes e-business and manufacturing strategies and creates a roadmap for system development and implementation in the plant. Another popular definition, by Koç et al. [3], describes emanufacturing as a system methodology that enables manufacturing operations to integrate successfully with the functional objectives of an enterprise through the use of the internet, tether-free (e.g., wireless, web, etc.), and predictive technologies. Generally, emanufacturing can be described as the application of the internet to manufacturing, as stated by Geng [4]. In the context of this research, we use the definition of emanufacturing offered by Geng [4]. In this study, for example, the intranet is used to monitor and control a tea-drying furnace.

E-manufacturing integrates hardware controls, information systems, and advanced decision technologies such as industrial engineering, operations research, artificial intelligence, and queuing theory [5]. E-manufacturing optimises the use of production assets based on information exchange from shop-floor operations across the enterprise to the whole supply chain [6]. Its ability to integrate manufacturing information systems and plant controls gives management the ability to monitor plant floor assets and enable real-time decisionmaking [7].

\section{CONTROL IN TEA DRYING}

The main objectives of tea drying are to preserve the tea leaves and produce a stable, quality product by arresting enzyme activity, halting oxidation, and removing moisture from a leaf's particles [1]. The other aim of drying is to bring enzyme activity to an optimum before halting the chemical reactions [8]. According to Rudramoorthy et al. [9], $100 \mathrm{~kg}$ of fresh leaves produces, on average, $22.5 \mathrm{~kg}$ of dried tea that contains only 3-4 per cent of residual moisture. The $77.5 \mathrm{kgs}$ difference between the fresh leaves and the dried tea represents the moisture that was evaporated during the process of withering and drying: approximately $20-25 \mathrm{~kg}$ is evaporated during the withering process, and around $20-50 \mathrm{~kg}$ is evaporated during the drying process. Drying time is approximately 20 minutes [10].

Since the labour costs of tea production in Zimbabwe are low, automation, monitoring, and process control were not really an issue for a long time. Companies are, however, becoming increasingly concerned about the operational and energy costs in tea processing because 
they are becoming highly energy-intensive. This is the case in Sri Lanka, for example, where the tea industry is the largest consumer of firewood and electricity, and almost the second largest consumer of oil [11]. There is therefore a need to develop more energyefficient technologies. A great deal of energy can be saved in tea production if the tea drying process is controlled. According to Bagheri et al. [12], a ten per cent increase in profit can be achieved by increasing energy efficiency by only one per cent.

The issues that need to be taken into consideration when drying tea include monitoring and detecting the inlet and outlet air temperature, the drying time, the air volume, and the feed tea, which can differ in its moisture contents and grade. In most factories in Zimbabwe, process control in tea drying is carried out manually. Typical dryer capacity fluctuates from approximately $100 \mathrm{~kg} / \mathrm{hr}$ to $300 \mathrm{~kg} / \mathrm{hr}$, and the average fuel consumption is around $45 \mathrm{~kg} / \mathrm{hr}$. Absence of an energy use control system leads to energy waste and to lower throughputs [13]. Even though producers are aware of the importance of process control and how it leads to better quality, they are reluctant to invest in high technology equipment.

\section{PROBLEM ENVIRONMENT}

The case study company in this research uses a three-stage tempest dryer that is fired by both electricity and diesel. Figure 1 is a schematic diagram that shows the hot air that is introduced into the dryer. As air is drawn into the heat banks by means of a fan, it passes over hot electrical elements before being heated by a diesel burner through a heat exchanger. The burner is fired through a nozzle pair. Nozzle 1 is called the High Temperature (HT) nozzle because it is switched on only when there is the need for high temperatures (e.g., when temperatures drop). Nozzle 2 is the Low Temperature (LT) nozzle, as it is always kept firing. Size 2.5 and 3.5 nozzles are normally used, while a 6 and 7 pair is used when drying using diesel only (e.g., during electricity power cuts). Dryer stoppage averages approximately 12 per cent of the total production time due to changes in the ambient conditions of the dryer and the changes in weather. These changes actually add to the production costs, since the tea is fed back into the dryer (i.e., re-fired).

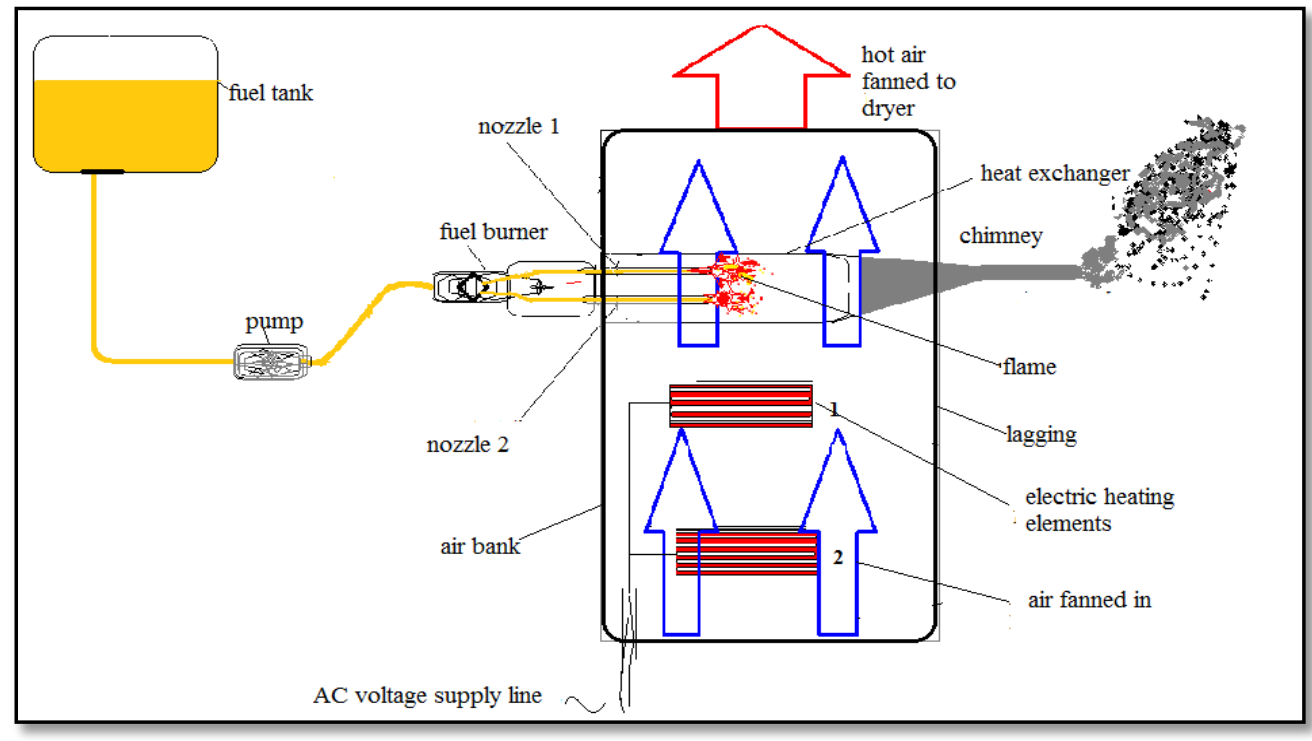

Figure 1: Schematic of the drying system

Dryer operators are stationed at the dryer exit where they 'feel' and 'smell' the tea, as shown in Figure 2. If the tea is under-fired or over-fired, the operator makes suitable adjustments to the temperature. These control actions include switching burner nozzles on or off and, in some cases, stopping the total production line. Every 30 minutes, samples are 
taken to the tea tasters who carry out various decoction and dhool tests, and then give feedback on the quality of the tea after a further 20 to 30 minutes. Quality control is therefore periodic, not continuous. As a result, at a production rate of $300 \mathrm{~kg} / \mathrm{hr}, 100-150$ $\mathrm{kg} / \mathrm{hr}$ of under- or over-fired tea can be produced without detection during the periods between tests.

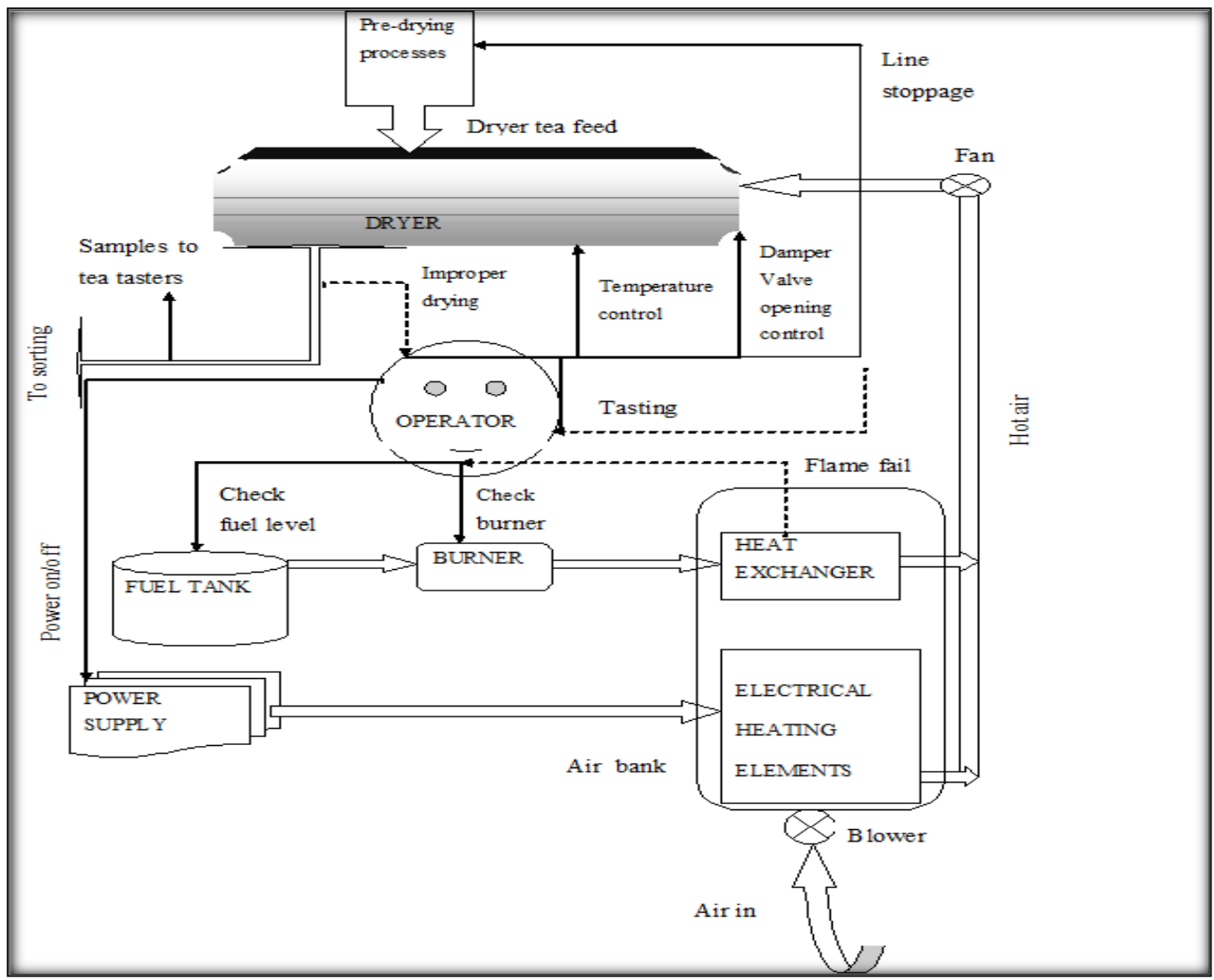

Figure 2: Dryer operators' functions

Line stoppages usually result in high temperature stewing and blanketing. During a typical line stoppage, under-fired tea is kept in buckets before being taken for re-firing. Tea from these buckets produces moisture, particularly at the bottom, and if delayed by 7-10 minutes before being sent for the second fire, the result is a 'stewed' tea with a soft and flat liquor.

From the investigation conducted at the case study company, the main sources of the drying problems were found to include the following:

1. Temperature and humidity fluctuations within the dryer;

2. Burner flame failure; and

3. Absence of airflow in the banks.

Flame failure is difficult to detect for most operators, as a result of the dryer design. An automatic control system is therefore needed to help ensure that the tea is always adequately dried, and to eliminate line stoppages and the need for any re-firing. 


\section{METHODOLOGY}

To investigate the current operations and problems, face-to-face interviews were conducted with the case study company's management and operators, and experiments were carried out at the company. Requirements analysis, functional analysis, and determination of optimal operating conditions (control model design) were carried out using the results from the investigation and the data gathered from relevant literature. A model and web application was designed, based on the Barix control application and hypertext markup language (HTML).

\subsection{Requirements analysis}

According to Leonard [14], requirements are the primary focus in the systems engineering process, since its primary purpose is to transform the requirements into designs within certain constraints. Ross and Schoman [15] emphasise the importance of requirements definition: it encompasses all aspects of system development prior to actual system design. Requirements analysis is critical to the success of a systems or software project. The aim of the analysis is to translate customer requirements into functional requirements that define what the system must do and how well it must perform [16]. It must ensure that the requirements are understandable, unambiguous, documented, actionable, measurable, testable, traceable, complete, concise, related to identified business needs or opportunities, and defined to a level of detail that is sufficient for system design. Requirements analysis must clarify and define functional requirements and design constraints. Functional requirements define quantity (how many), quality (how good), coverage (how far), time lines (when and how long), and availability (how often). Design constraints define those factors that limit design flexibility, such as environmental conditions or limits; defence against internal or external threats; and contract, customer, or regulatory standards [17].

A quality function deployment (QFD) analysis was made using a scale of 1-5 to rate the important factors, with 1 representing the least important factor and 5 representing the most important factor. The requirements for the control system were classified into three categories: management's, operators', and customers' requirements.

Using the dryer book, cell distortion unit book, production sheets, and interviews conducted with the operators, the following operators' requirements for the controller were found to be important:

1. Should have fewer stoppages (5);

2. Comfortable working temperature (4);

3. Easy to detect flame failure (4); and

4. Less handling of tea (4).

From the interviews with management and from their production reviews, the following management requirements were observed:

1. Should produce properly-fired tea (5);

2. Should be fuel efficient (4);

3. Production should end within the projected duration (4); and

4. Tea should have highest possible market value (4).

From interviews with vendors and blenders, including an analysis of customer orders, the following customer requirements were found to be important:

1. Batch should have a high decoction quality (5);

2. Should produce cheap tea (4);

3. Should produce an odourless tea (4); and

4. Tea should have a long shelf life (3). 
The technical requirements were determined and rated in order of importance (maximum temperature, drying rate, fuel feed rate, sensor type, component size, tea outlet temperature, and operating voltage) to identify the critical areas in the controller design.

\subsection{Function analysis and allocation}

Blanchard and Fabrycky [17] highlight that the purpose of functional analysis and allocation is to understand better what the system has to do, how it can do it, and to some extent, the priorities and conflicts associated with lower-level functions. Functional analysis provides information that is essential for optimising physical solutions. Key tools in functional analysis and allocation include functional flow diagrams, time line analysis, and the requirements allocation sheet. Functions are discrete actions necessary to achieve the system's objectives, and may be stated explicitly or derived from stated requirements. These are actions that will ultimately be performed or accomplished through the use of equipment, personnel, facilities, software, or a combination of these [14]. The performance requirements associated with the higher level are allocated to lower functions. The laymen's language is transformed into technical language to describe the production in terms of what it does logically, and in terms of the performance required. A House of Quality was used to correlate customer importance to the product functions, as stated by Little et al. [16]. We used the QFD to identify customers' wishes (from market research, data mining, system analysis, etc.), learn technical methods, correlate the customers' needs with technical regulations, and benchmark these into a number of priority targets, as shown in [18].

One of the important requirements for the proposed tea drying control system is that it should be able to troubleshoot against flame failure and the absence of bank airflow, on top of temperature/moisture control. Using the technical requirements, a functional architecture of the system was developed. Temperature control will be achieved by the conditional firing of HT and LT nozzles. To control the decoction quality of tea, the drying rate is made constant by regulating the fuel feed for various temperature ranges. Keeping the fuel feed constant and controlling temperature makes the system less complex.

\section{DESIGN OF THE CONTROL SYSTEM MODEL}

The control system model was developed using the dryer exhaust temperatures approach suggested by Temple and Van Boxtel [19], and optimal operating parameters determined using the Guggeiheim-Anderson-De Boer (GAB) model that was developed by Guggenheim, Anderson and De Boer [20] and proved by Lewicki [21]. This is given by Equation 1.

$$
M_{e}=\frac{\left(a_{w} M_{m} C K\right)}{\left[\left(1-K a_{w}\right)\left(1+C K_{a}-K a_{w}\right)\right.}
$$

where $M_{e}$ is the equilibrium moisture content (\% dry basis). Water activity $a_{w}(0$ to 0.9$)$ is the state of water in food and the degree at which it interacts with other components. C and $\mathrm{K}$ are given by Equations 2 and 3 . $\mathrm{K}$ measures the difference of the chemical potential standard between the molecules of the sorbing material and those of the pure liquid state [19].

$$
C=C_{o} \exp \left(\frac{C_{1}}{R T_{a b}}\right)
$$

where $T_{a b}$ is the absolute temperature (K), R is the universal gas constant $(8.32 \mathrm{~kJ} / \mathrm{mol} \mathrm{K})$, and $C_{0}$ and $C_{1}$ are entropic accommodation factors equal to 0.02521 and 14644.71 respectively [20].

$$
K=K_{o} \exp \left(\frac{C_{1}}{R T_{a b}}\right)
$$

where $K_{0}$, and $K_{1}$ are entropic accommodation factors equal to 0.99328 and -147.031 respectively [21] 


$$
T_{S}=T_{M}-T_{A}
$$

where $T_{S}$ is the time saved due to automation, $T_{M}$ is the drying time without automation, and $T_{A}$ is the drying time under automation.

$$
C_{A}=C_{H S}+C_{D M}+C_{T}
$$

where $C_{H S}$ is the cost of hardware and software, $C_{D M}$ is the cost of developing and maintaining automation script, and $C_{T}$ is the cost of training staff on automation tools.

No major changes need to be made to the existing hardware. $C_{H S}$ includes the cost of barionets (US\$ 400-600), computers (minimum of US\$ 400), and sensors. No specialised software is required for the script, and the minimum cost of internet services is approximately US\$ 75 per month in Zimbabwe.

The GAB model derives its superiority from the fact that it has a viable theoretical background and is a refinement of other models, such as the Langmuir and BET theories of physical adsorption. It takes into consideration the modified properties of sorbate materials in a multilayer region [21]. Many micro-organisms cannot grow if the water activity is below 0.9 , most moulds require a water activity above 0.8 , and a water activity below 0.6 will inhibit all microbial growth [20].

The quality or the grade of tea is shown ultimately in its value. In an experiment by Temple and Van Boxtel [19], the value of tea showed a logarithmic relationship with time.

$$
V=132-0.27 T-5 \log t
$$

where $\mathrm{V}$ is the value (US cents/ $\mathrm{kg}$ ), $\mathrm{T}$ is the drying temperature $\left({ }^{\circ} \mathrm{C}\right.$ ), and $\mathrm{t}$ is the drying time (minutes). A typical first grade tea has a value of approximately US $\$ 0.95 / \mathrm{kg}$. As can be seen from the above equation, a reduction in drying time leads to an increase in value. A reduction in dryer stoppages is one way of minimising the time taken by the tea in the dryer.

For the drying requirements at the case study company, a water activity of 0.6 is seen as adequate. Matlab was used to plot the GAB variable $C$ against Temperature (C-T), GAB variable $k$ against Temperature $(k-T)$, and moisture content vs Temperature $(m-T)$ graphs, as shown in Figures 3, 4, and 5.

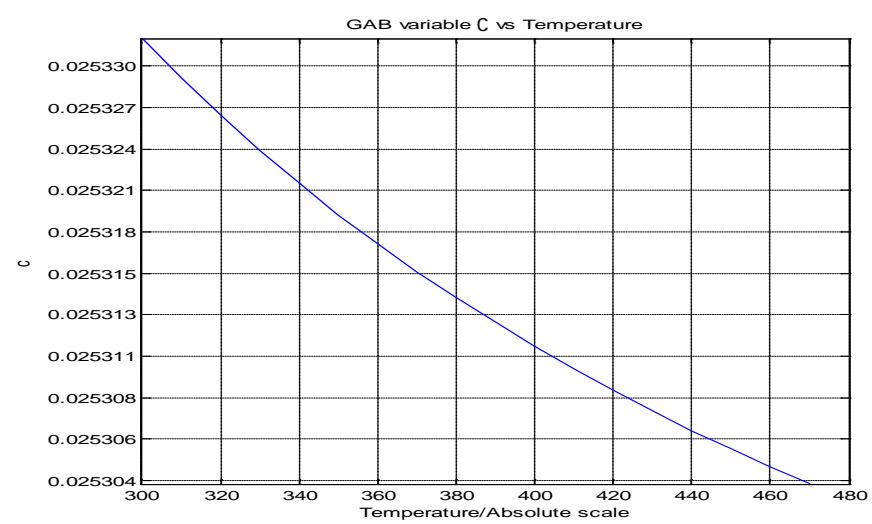

Figure 3: The graph of GAB variable $C$ vs temperature 


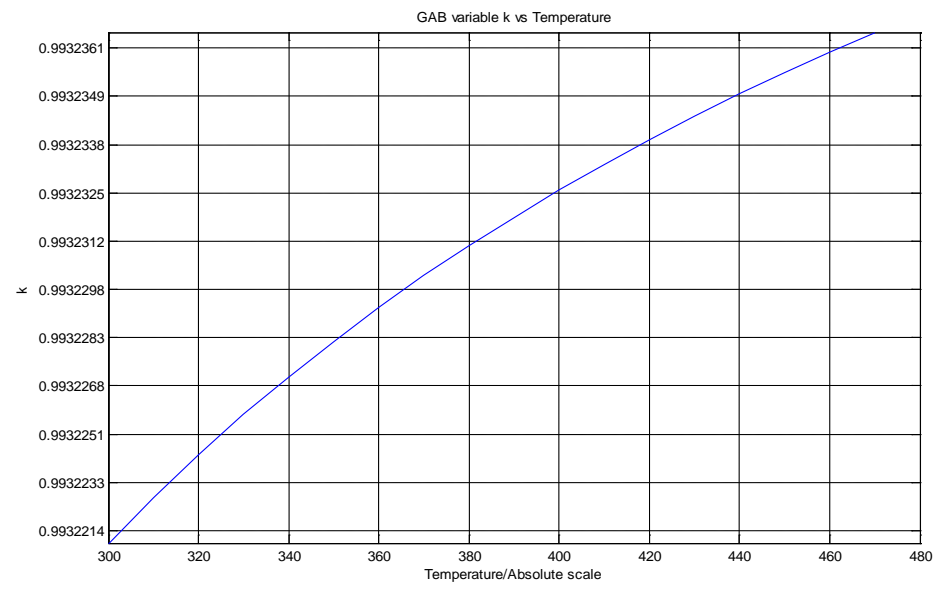

Figure 4: The graph of GAB variable $K$ vs temperature

The results of the effects of the drying rate on tea quality, which were established from experiments by Temple et al. [8], are shown in Table 1. From the total scores in Table 1, it can be observed that as the inlet temperature increases, some characteristics improve while others deteriorate. The most desired tea is dried at $100^{\circ} \mathrm{C}$. Interpolation of the graph of moisture content against temperature was used to calculate the maximum temperature needed to achieve the company's target drying rate of 3 per cent per minute.

$$
\begin{aligned}
& \frac{120-100}{3.041-2.976}=\frac{T-100}{3-2.976} \\
& T=107.30
\end{aligned}
$$

A range of $100-110^{\circ} \mathrm{C}(373-383 \mathrm{~K})$ is used, however. From Figure 5, this yields a moisture content of approximately 3.119 per cent.

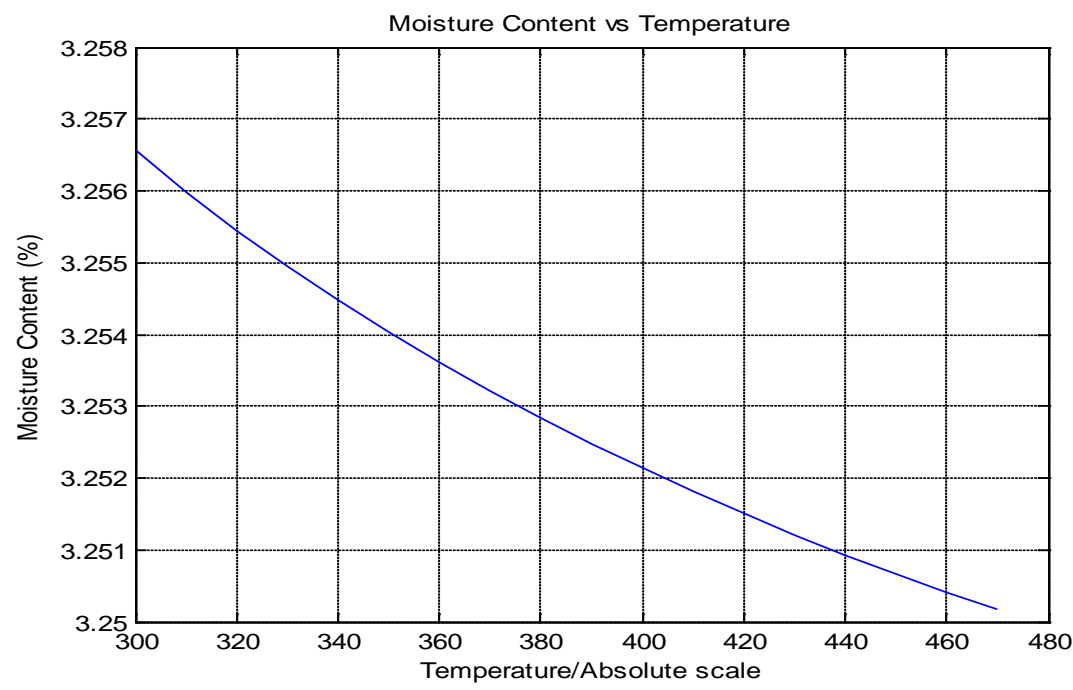

Figure 5: The graph of moisture content vs temperature 
Table 1: The effects of temperature and drying rate on tea [8]

\begin{tabular}{|c|c|c|c|c|c|}
\hline Inlet temperature $\left({ }^{\circ} \mathrm{C}\right)$ & 60 & 80 & 100 & 120 & 140 \\
\hline Drying rate $\% \mathrm{~min}$ & 2.168 & 2.482 & 2.976 & 3.7615 & 4.227 \\
\hline Black tea & brown & blackish & blackish & blackish & blackish \\
\hline Infusion appearance & $\begin{array}{l}\text { Bright, } \\
\text { coppery }\end{array}$ & $\begin{array}{c}\text { fair } \\
\text { brightness, } \\
\text { coppery }\end{array}$ & $\begin{array}{c}\text { some } \\
\text { brightness, } \\
\text { coppery }\end{array}$ & $\begin{array}{c}\text { some } \\
\text { brightness, } \\
\text { coppery }\end{array}$ & dull \\
\hline Liquor appearance & useful & light harsh & $\begin{array}{c}\text { full fired, } \\
\text { harsh }\end{array}$ & burnt & $\begin{array}{l}\text { very } \\
\text { burnt }\end{array}$ \\
\hline *Colour score & 5.5 & 6 & 6 & 6 & 5 \\
\hline *Strength score & 5 & 4 & 4.5 & 3.5 & 3.5 \\
\hline *Briskness score & 5 & 4 & 5 & 4 & 4 \\
\hline *Brightness score & 6 & 5 & 5.5 & 4 & 3 \\
\hline *Thickness score & 4 & 4.5 & 5 & 4 & 5 \\
\hline **Total score & 25.5 & 23.5 & 26 & 21.5 & 20.5 \\
\hline
\end{tabular}

*Represents the tea testers' score, which ranges from 6 (excellent) to 0 (extremely poor)

**T otal of the scores for colour, strength, briskness, brightness, and thickness.

\subsection{The Barionet and the Barix Control application}

Control activities are achieved by using the network capabilities of the Barionet via the web browser. The application developed is capable of switching the HT nozzle on and off, and signalling alerts when critical levels of fuel and/or moisture content are reached, when there is flame failure, and/ or when there is no adequate airflow in the banks. Moisture control is to be achieved through drying temperature control. This means that an acceptable change in moisture content is due solely to a critical system failure; thus the moisture detector is programmed to stop the whole system and sound an alarm in such an event. The operator can switch the system components on or off from the web user interface (WUI).

Temperature measurement was done using a Dallas wire temperature sensor, and a capacitive moisture sensor was used to detect the moisture. Flame detection was achieved by a flame ionisation detector, since it encourages the use of fuels with low sulphur and nitrogen contents. A pitot-static tube was used for airflow detection, and a capacitive liquid sensor was found to be the best candidate for fuel level measurement for this application because of its accuracy.

The functional flow diagram for the system is shown in Figure 6 . The control system achieves temperature/moisture control by the conditional switching on or off of the HT and LT nozzles. During normal drying, the HT nozzle is off and the LT nozzle is firing. Due to moisture build-up in the dryer, the temperatures are bound to fall beyond the preset minimum value. When that happens, the HT nozzle is switched on and subsequently switched off when temperatures rise beyond the preset maximum value. In the case of the proposed controller, moisture control is achieved by temperature control, so as to avoid a multi-variable system that would make the system less complex. The system also troubleshoots against flame failure and the absence of bank airflow. With this kind of system, preset critical maximum or minimum moisture content levels are only reached when there is a serious failure within the system (e.g., power failure or mechanical problems). When there is a serious failure, the system stops and sounds an alarm.

The tea drying system control page is the index page, and is connected to five 'control settings' pages, as shown in Figure 7. HTML links should therefore be provided for the user to be able to navigate among the pages on the intra/ internet. 


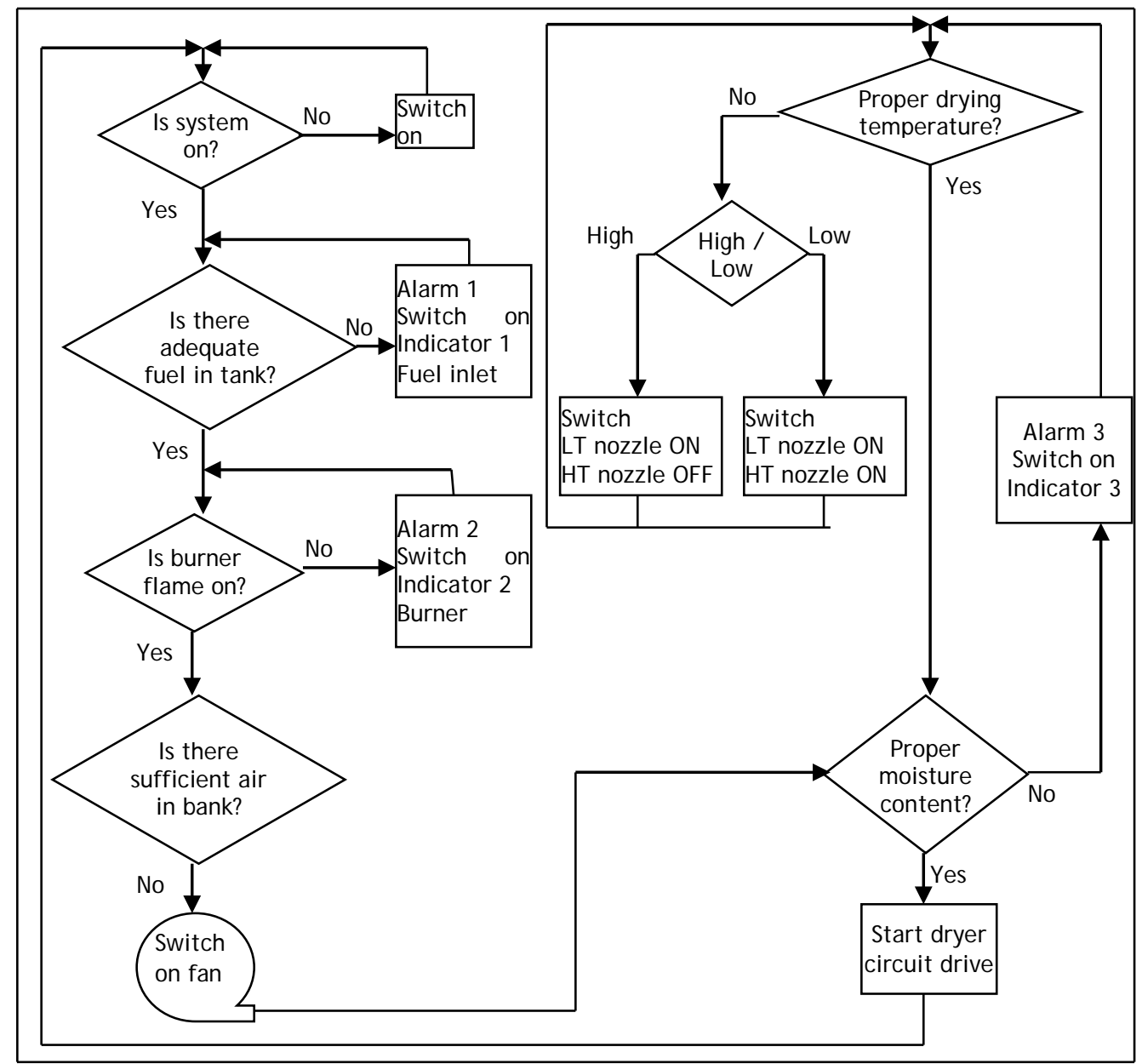

Figure 6: Functional flow diagram

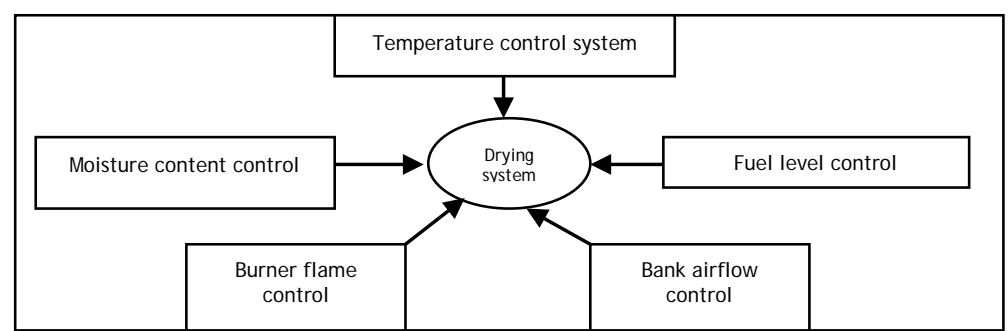

Figure 7: System modules

\section{RESULTS AND DISCUSSIONS}

The system is controlled from a web-based switchboard. The user interface consists of a web page developed in HTML, as shown in Figure 8. Real-time dryer control and monitoring can be achieved from the office, which is networked to the controller. The web page is set up to refresh after every two seconds, which gives more up-to-date information on the conditions in the dryer, compared with waiting for 30 minutes to get results from the tea testers. This enables total quality management (TQM) in the system, as quality is built into the process, compared with the quality inspection that is done currently. 


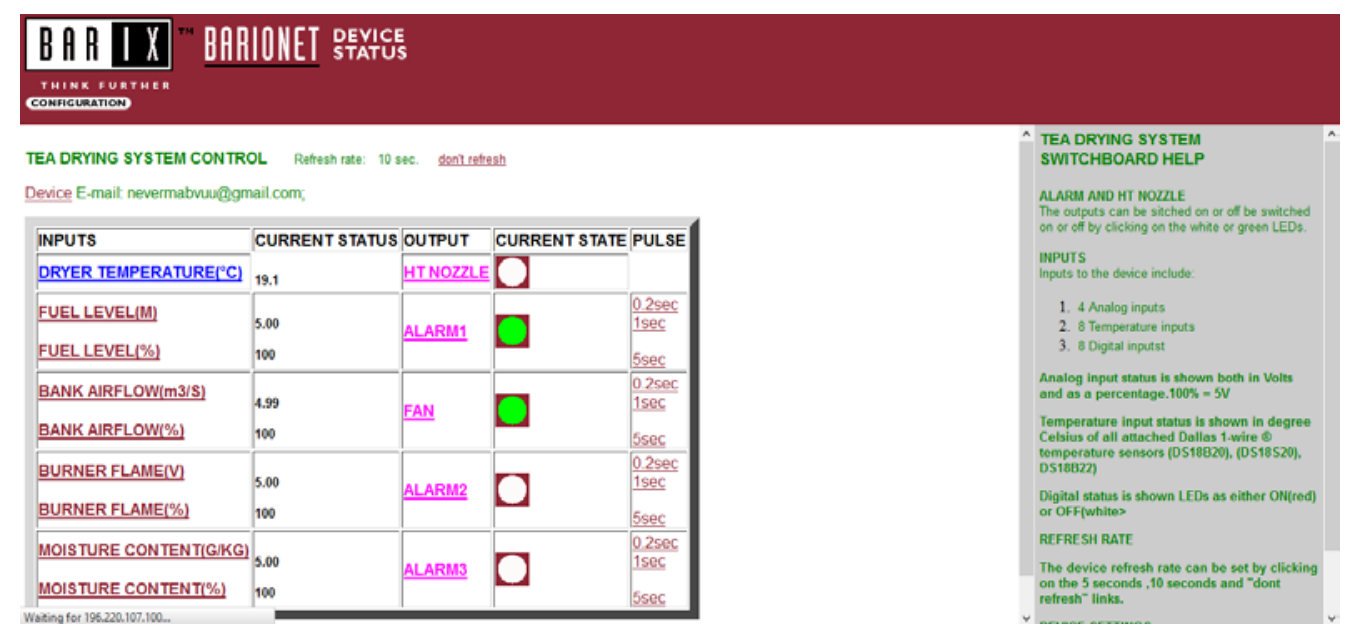

Figure 8: Tea drying system switchboard

The links given on the main switchboard can be used to set parameters to the desired limit values. Figure 9 shows the web page for setting up control variables for temperature.

To meet the requirements of the dryer at the case study company, the dryer operation parameters, which were calculated using the GAB model discussed in Section 6, were set as shown in Table 2.

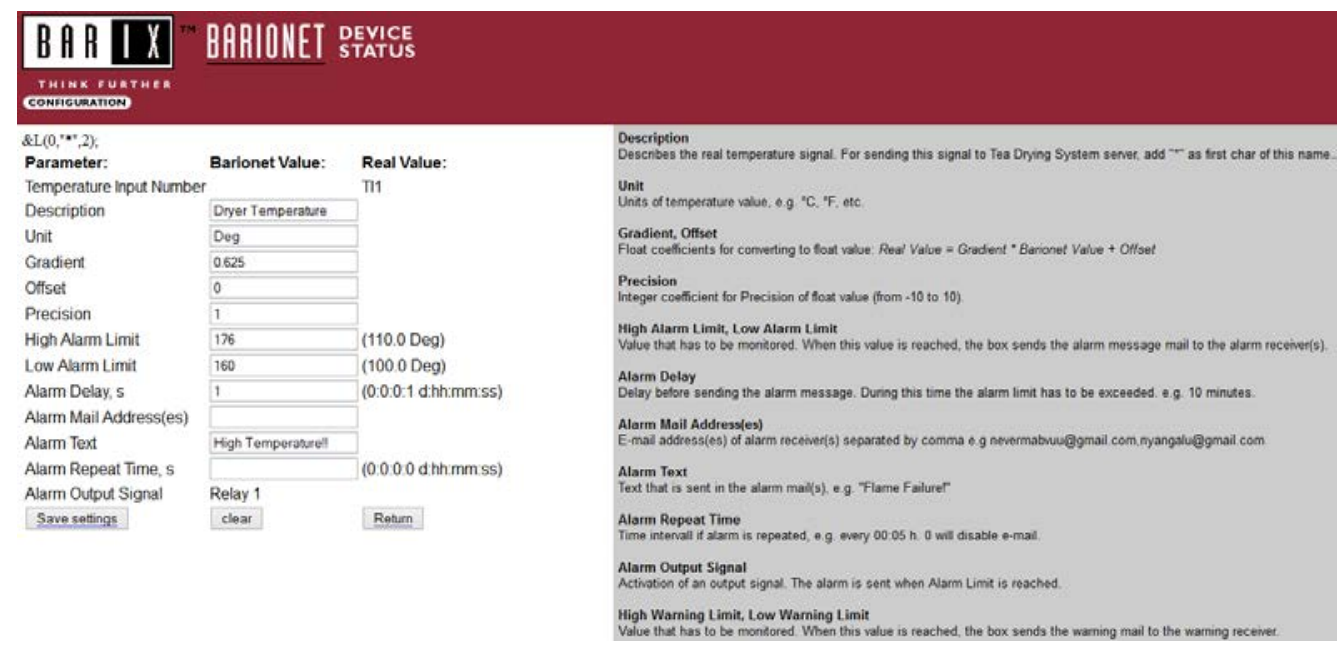

Figure 9: Temperature parameters settings webpage

Table 2: Dryer Control parameters

\begin{tabular}{|l|c|}
\hline \multicolumn{1}{|c|}{ PARAMETER } & V VALUE \\
\hline Minimum temperature & $100^{\circ} \mathrm{C}$ \\
\hline Maximum temperature & $110^{\circ} \mathrm{C}$ \\
\hline Drying rate & $3.0 \%$ per min \\
\hline Dryer exit tea moisture content & $3.0-3.12 \%$ \\
\hline
\end{tabular}

The system is able to address the requirements of the operator, management, and vendor. It achieves fewer stoppages and increases fuel efficiency by maintaining the control variable in the calculated control variables developed by the GAB. This also enables the company to maintain high decoction quality in the batches produced. The operators are able to control the furnace from their offices - a more comfortable environment than being 
near the furnace, as is required by the current system. The flame detector is used to detect flame failure, which is difficult to detect manually because of the design of the burner. It reduces stoppages during production, which in turn increases the volumes produced and reduces the cost price for the tea produced, as required by the vendors. The introduction of the TQM methodology results in less handling of tea and the tea being properly fired, as required by management. At a drying rate of 3 per cent per min, an average drying time of 7-16 minutes is achievable. According to Equation 6, this produces teas with values between 96.3 and 100.8 US cents/ $\mathrm{kg}$.

The control system is flexible, and its use can be extended to include industrial functions such as condition-based maintenance, as long as the proper selection of sensors and other auxiliary devices is used. The effect of airflow on tea drying can be complex, and so future studies need to be conducted on this. Temperature control is not the only route to quality tea production; it should be supported by other functions such as maintenance, quality control, and production management. It is also necessary to strive to maintain a constant dryer federate during the process of tea drying, so as to eliminate variable fluctuations within the dryer atmosphere.

The system is not only limited to tea drying; it can be applied to a variety of industries that use dryers, such as the textile, paper and pulp, chemical, pharmaceutical, food, and dairy industries. The system shows how e-manufacturing can help to monitor and improve production in companies. The decision-makers in the companies can then make informed decisions that are based on readily-available, real-time data of what is actually taking place in the factory.

\section{CONCLUSION}

E-manufacturing integrates hardware controls, information systems, and advanced decision technologies. It enables decision-makers in companies to monitor the processes in the factory using up-to-date information. The control system discussed in this paper uses an emanufacturing methodology to monitor and control the conditions inside a tea dryer. The system enables quality to be built into the process of drying tea by keeping the conditions within the required range, instead of depending on the results of quality inspection that is done periodically and can result in the loss of valuable information generated by the dryer. The system uses the GAB model with an optimum drying temperature range of $100-110^{\circ} \mathrm{C}$, a dryer exit tea moisture content of 3 to 3.12 per cent, and a drying rate of 3 per cent per minute. A Barionet controller is used as the main controller for the system.

\section{REFERENCES}

[1] Saeed, I.E., Sopian, K. \& Zainol, A.Z. 2008. Thin-layer drying of roselle (i): Mathematical modeling and drying experiments. Agricultural Engineering International: the CIGR Ejournal, Manuscript FP 08 015, Vol. X, September.

[2] AMR. 2000. An e-manufacturing strategy needs to be developed from the manufacturing strategy, AMR Research, Inc., August.

[3] Koç, M., Ni, J., Lee, J. \& Bandyopadhyay, P. 2003. Introduction of e-manufacturing, NAMRC 2003 E-Manufacturing Panel, McMaster University, May.

[4] Geng, H. 2004. Manufacturing engineering handbook, $1^{\text {st }}$ edition, McGraw Hill.

[5] Zhang, M.T., Fowler, J., Chen T.W.Y., Shanthikumar, J.G. \& Chien, C-F. 2007. Editorial: Emanufacturing in the semiconductor industry. IEEE Transactions on Automation Science and Engineering, 4(4), pp. 485-487.

[6] Wang, D. 2007. An information-integrated framework to support e-manufacturing. The International J ournal of Advanced Manufacturing Technology, 32, (5-6), pp. 625-630.

[7] Lee. J. 2003. E-manufacturing - fundamental, tools, and transformation. Robotics and Computer Integrated Manufacturing, 19, pp. 501-507.

[8] Temple, S.J., Temple, C.J. \& Clifford, M.N. 2001. The effect of drying on black tea quality. J ournal of the Science of Food and Agriculture, 81(8), pp. 774-772.

[9] Rudramoorthy, R., Sunil Kumar, C.P., Velavan, R. \& Sivasubramaniam, S. 2000. Innovative measures for energy management in tea industry, Proceedings of the $42^{\text {nd }}$ National Convention of Indian Institute of Industrial Engineering, Coimbatore, India, Sept 29-30, pp. 163-167. 
[10] Devki Energy Consultancy. 2006. Dryers, best practice manual. Retrieved from http:// www. energymanagertraining. com/ CodesandManualsCD-5Dec\%2006/

BEST\%20PRACTICE\%20MANUAL\%20-\%20DRYERS. pdf. Accessed on 30 May 2013.

[11] Ziyad, M.M.T. \& Zoysa, A.K.N. 2006. Current status and future research focus of tea in Sri Lanka, J ournal of Agricultural Sciences, 2(2), pp. 32-34.

[12] Bagheri, N., Keyhani, A., Mohtasebi, S.S., J avadikia, P. \& Abbaszadeh, R. 2012. Simulation and control of fan speed in a solar dryer for optimization of energy efficiency. Agricultural Engineering International: CIGR J ournal, 14(1), pp. 57-62.

[13] J aranmard, M., Abbas, K.A. \& Arvin, F. 2009. A microcontroller-based monitoring system for batch tea dryers. J ournal of Agricultural Science, 1(2), pp. 101-106.

[14] Leonard, J . 1999. Systems engineering fundamentals: Supplementary text. DIANE Publishing.

[15] Ross, D.T. \& Schoman, K.E. 1977. Structured analysis for requirements definition. Software Engineering, IEEE Transactions, (1), pp. 6-15.

[16] Little, A.D, Wood, K.L. \& McAdams, D.A. 1997. Functional analysis: A fundamental empirical study for reverse engineering, benchmarking, and redesign. 9th International Conference on Design Theory and Methodology, Sacramento, California.

[17] Blanchard, B.S. \& Fabrycky, W.J . 1990. Systems engineering and analysis. $4^{\text {th }}$ edition, Prentice Hall.

[18] Suprihatini, R. 2009. Application of quality function deployment in orthodox black tea industry in Indonesia. Indonesian J ournal of Agriculture, 2(1), pp. 28-34.

[19] Temple, S.J . \& Van Boxtel, A.J .B. 2001. Automatic endpoint determination for batch tea dryer. J ournal of Agricultural Engineering Research, 78(1), pp. 51-56.

[20] Panchariya, P.C., Popovic, D. \& Sharma, A.L. 2002. Desorption isotherm modelling of black tea using artificial neural networks. Drying Technology: An International J ournal, 20(2), pp. 351-362.

[21] Lewicki, P.P. 1997. The applicability of the GAB model to food water sorption isotherms. International J ournal of Food Science and Technology, 32(6), pp. 553-557. 